\title{
Hereditary Pituitary Dwarfism with Spontaneous Puberty
}

\author{
M. SEIP, C. B. VAN DER HAGEN, and O. TRYGSTAD \\ From the Paediatric Department and Paediatric Research Institute, University Hospital, Oslo, \\ and the University Institute of Medical Genetics, Oslo, Norway
}

It is now well established that pituitary dwarfism may be recessively inherited (Hanhart, 1925; Nowakowski and Lenz, 1961; Trygstad and Seip, 1964; Rimoin, Merimee, and McKusick, 1966). The condition has repeatedly been observed in sibs (Biben and Gordan, 1955; Schärer and Prader, 1960; Nowakowski and Lenz, 1961; Trygstad and Seip, 1964; Bierich, 1964; Brasel, Wright, Wilkins, and Blizzard, 1965; Rimoin et al., 1966), and sometimes as the result of consanguineous marriages (Hanhart, 1925; Rimoin et al., 1966; this report), or in cousins (Trygstad and Seip, 1964). Probably the 28 cases of inherited dwarfism reported by Hanhart in 1925 from Oberegg and Samnauntal in Switzerland, and from the island of Veglia in Yugoslavia, were of pituitary origin, though diagnostic criteria were less well established at that time.

It has been commonly believed that pituitary dwarfs do not mature sexually, or at least do so very poorly, due to lack of pituitary gonadotropic hormones in addition to the somatotropin deficiency. But this is not always the case (Hewer, 1944; Antonin, 1961; Bierich, 1964; Brasel et al., 1965; Rimoin et al., 1966).

At least four different forms of inherited pituitary dwarfism seem to have been established. (a) In the most common, all or several anterior pituitary hormones are deficient, though often to a variable degree. These dwarfs do not mature sexually.

(b) Steiner and Boggs (1965) have described congenital absence of the pituitary gland with hypothyroidism, hypoadrenalism, and hypogonadism in two sibs, brother and sister, offspring of first-cousin parents.

(c) Laron, Pertzelan, and Mannheimer (1966) have reported an interesting sibship with evidence of a functional deficiency of growth hormone, though radioimmunoassay gave high values of

Received April 27, 1967. serum growth hormone. An abnormal, biologically inactive growth hormone in high concentration is a reasonable assumption in these patients since they responded well to exogenous growth hormone.

(d) The fourth group includes dwarfs with documented, isolated growth hormone deficiency with low plasma growth hormone levels by radioimmunoassay (Rimoin et al., 1966; this report).

The present report is of a family in which 3 of 9 sibs are affected by pituitary dwarfism. 2 of these patients have gone into spontaneous puberty, and the third probably will. The parents are first cousins. The youngest of the affected sibs has been successfully treated with human growth hormone for more than two years. The results of growth hormone determinations and of studies of genetic marker systems in this family (in order to demonstrate possible genetic linkage) are reported.

\section{Methods}

Skeletal age standards were those of Greulich and Pyle (1959). The metyrapone test was performed by the oral administration of 70-80 mg./kg. divided in 6 doses in 24 hours, the daily excretion of 17-OHCS and 17-KS being measured one day before, during, and the day after. Insulin sensitivity was studied by means of a combined insulin-glucose tolerance test (Trygstad, 1965). Plasma growth hormone was determined radioimmunologically by Dr. Nils Norman, Aker Hospital, Oslo, Norway, before and one hour after i.v. insulin injection $(0 \cdot 1$ I.U./kg.). The tests were performed in the morning in the fasting state.

The material for linkage calculation is given in the Appendix (Table I). Tests were made for the following factors: $A, A_{1}, B, M, N, S, s, C, c, D, E, L e(a), P$, Fy(a), K, PTC, Gm (1, 2, 4, 5, 21), Inv $(1,3), \mathrm{Pi}$, PGM, Tm, Gc, Lp(a). Statistical analyses for linkage relations were performed by the Fisher-Finney method (Finney, 1940) and the Morton-Smith method (Smith, 1959), using electronic computer programs (Mohr, 1966) with some revisions (Gedde-Dahl and Monn, 1967). 


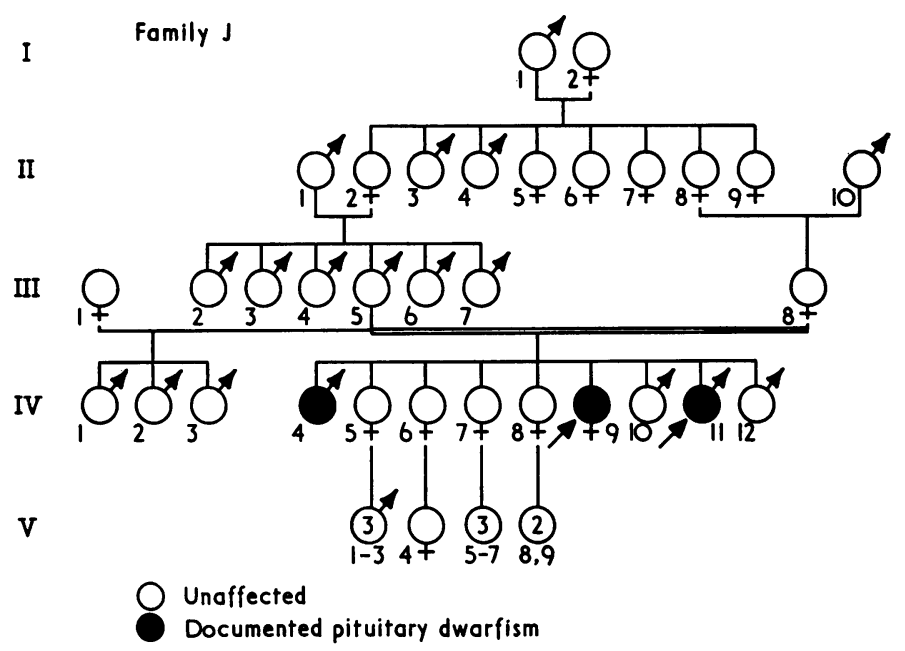

FIG. 1.-Pedigree of the family. Arrows indicate probands.

\section{Case Reports}

Case 1. IV. 4 (see Fig. 1) was born on September 9,1930 , following normal pregnancy and delivery. His rate of growth was slow from the first year of life, though his intellectual development has been normal. Puberty was delayed, starting at 17, but was completed spontaneously. The external genitals are of normal adult size (Fig. 2). Pubic hair, body hair, and beard are well developed. He has normal libido, and has had several sexual contacts with the opposite sex, but has not married.

He continued to grow until he was over 20 , and has reached an ultimate height of $142 \mathrm{~cm}$. Epiphysial fusion is now complete. In adult life moderate obesity has developed, his weight being $64 \mathrm{~kg}$. His short stature has led to emotional problems, and he has been under treatment for abuse of alcohol. He is employed by the local telephone company.

The most important laboratory findings are given in the Appendix (Table II).

Case 2. IV. 9 was born on December 9, 1945, following normal pregnancy and delivery. Her birthweight was $3000 \mathrm{~g}$. Growth retardation was apparent in infancy and became very marked. She also has bilateral dislocation of hip joints. Her intelligence and school progress have been normal.

At the age of 8 years and 10 months she was $88.5 \mathrm{~cm}$., and at 15 years she was $101.5 \mathrm{~cm}$., her weight being $14 \cdot 7 \mathrm{~kg}$.

She was admitted to our department in September 1964, aged 183. She measured $109 \mathrm{~cm}$. (height age $4 \frac{3}{4}$ years), and weighed $18 \cdot 2 \mathrm{~kg}$. There was breast development. Pubic hair was present, though sparse. Menarche had occurred at age 18 years and 4 months. The skeletal age was between 14 and 15 years. The epiphysial lines had started to fuse. Chromosome analysis was normal. Metyrapone test gave a normal response.

When restudied at the age of 21 she still measured $109 \mathrm{~cm}$., and the epiphysial lines were fused. She had regular, normal menses. Breast development was normal. Pubic hair was still sparse and axillary hair lacking (Fig. 2). Laboratory data are given in the Appendix (Table II).

Case 3. IV. 11 was born March 30, 1950, following normal pregnancy and delivery. His birthweight was normal. Psychomotor development was normal, but growth was retarded from the first years of life.

He was admitted to our department aged $14 \frac{1}{2}$. His height was $115 \mathrm{~cm}$. (height age 5 years and 2 months), weight $18 \cdot 8 \mathrm{~kg}$. Body proportions were normal, with no signs of sexual development. Skeletal age was 9 years. Pneumoencephalogram was normal. Chromosome analysis was normal. There was a normal response following metyrapone administration.

Treatment with human growth hormone, $2 \mathrm{mg}$. three times a week, was begun at the age of 14 years and 7 months, after which he grew $13 \mathrm{~cm}$. in 24 months, and there was a comparable advance of skeletal age.

When restudied in November 1966, at age $16 \frac{1}{2}$, he showed some growth of the external genitals, signifying incipient puberty (Fig. 2), though no pubic or axillary hair was present. The height was $128 \mathrm{~cm}$. Laboratory data are given in the Appendix (Table II).

\section{Discussion}

The pedigree of the reported family is shown in Fig. 1. The parents are first cousins. 3 of their children (IV. 4, 9, and 11), 2 males and 1 female, are dwarfs. The father has 3 sons of normal 


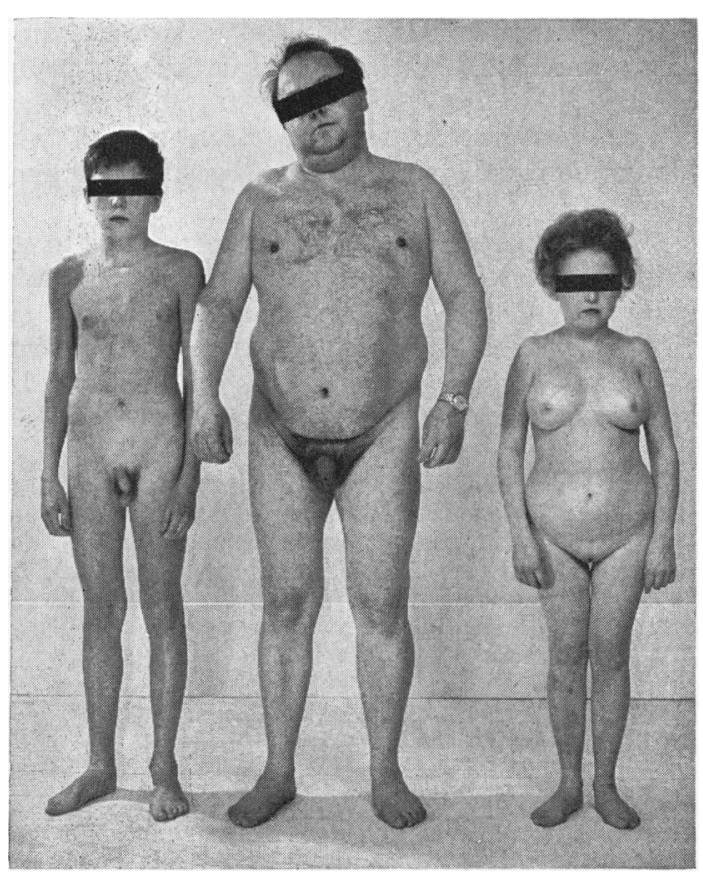

FIG. 2.-Three sibs with isolated growth hormone deficiency. From left to right, male, $16 \frac{1}{2}$ years, in incipient puberty, height $128 \mathrm{~cm} . ;$ male, 36 years, height $142 \mathrm{~cm}$.; female, 21 years, height $109 \mathrm{~cm}$.

stature by a previous marriage; no other cases of dwarfism are known in this family. The 4 normal sisters of our patients are married and have produced normal children. The 2 normal brothers are still in their teens. The mother was an only child. The father's 5 brothers are all married and have a total of 9 children all of normal stature.

All 3 patients were normally developed at birth and showed marked growth retardation from infancy. Body proportions are normal (Fig. 2). The oldest had shown complete sexual maturation, starting at 17 . He continued to grow until he was more than 20 , and had reached an ultimate height of $142 \mathrm{~cm}$. His younger sister, who in addition has bilateral hip dislocation, has also gone through spontaneous puberty, with menarche at 18 years and 4 months; she has normal breast development, but pubic hair is sparse, and axillary hair lacking. Her final height is $109 \mathrm{~cm}$. The youngest patient is now 17; his bone age is 11 years, and he is in incipient puberty.

The urinary output of pituitary gonadotropin is within normal limits in all 3: high normal in the oldest, low normal in the 2 youngest. The excretion of androgens is normal in Case 1. In his severely dwarfed sister, now 21 years of age, the excretion of dehydro-epiandrosterone, etiocholanolone, oestriol, and oestradiol is within normal limits, while androsterone and oestrone excretion is somewhat low. The younger brother is just in the beginning of his pubertal development, and the output of gonadal hormones is naturally still low.

The urinary 17-ketosteroids are below average for age, but probably within normal limits in all 3, when the size and the stage of pubertal development of the patients are taken into account. The same applies to the 17-hydroxysteroids. Metyrapone tests in the two youngest gave normal responses. Thus the corticotropin secretion in our group of patients can be taken to be normal.

Thyrotropin deficiency was not present, as PBI was normal in all 3 on repeated occasions. The serum cholesterol values were high, 309-360 mg./ $100 \mathrm{ml}$., but cholesterol levels in this range are frequently found in pituitary dwarfism, even when thyroid function is entirely normal.

The i.v. insulin tolerance test reveals increased insulin sensitivity in most but not all cases of pituitary dwarfism. Increased insulin sensitivity is judged to be present, either when the fall in blood glucose is excessive during the test, or when there is a continued fall from the 20 -minute to the 30 -minute sample (Trygstad, 1965). According to these criteria Cases 1 and 3 showed increased insulin sensitivity, and possibly also Case 2, though the response was borderline.

Plasma growth hormone determinations were performed in the morning in the fasting state, before and one hour after i.v. insulin administration. Low levels were found (around $1.0 \mathrm{~m} \mu \mathrm{g} . / \mathrm{ml}$.), and no increase followed insulin hypoglycaemia-diagnostic of somatotropin deficiency

The youngest patient, whose epiphyses are still open, had been treated with human growth hormone, $2 \mathrm{mg}$. three times a week, for two years and had grown normally $(13 \mathrm{~cm}$.) during this period. This favourable response confirms the diagnosis of pituitary dwarfism. For one year he received a supplement of $0.1 \mathrm{mg}$. thyroxin daily in addition to growth hormone. His rate of growth was exactly the same with and without thyroxin, a fact that confirms the normality of thyroid function.

We have good reason to believe that these patients have an isolated somatotropin deficiency. Gonadotropin secretion started relatively late in all three, but is now within normal limits. There are no signs of deficiency of other tropic pituitary hormones.

The occurrence of an isolated somatrotopin deficiency in 3 sibs of either sex, in a sibship of 9 , with normal parents and consanguineous marriage is in keeping with an autosomal recessive inheritance. 
Established cases of hereditary isolated growth hormone deficiency have been reported by Rimoin et al. (1966). They studied in detail 6 cases, belonging to 2 kindreds, with clinical pictures very similar to our patients. 4 of the 6 have produced children, proving that these subjects are fertile; lactation had also been normal. Puberty had been delayed by 2 to 10 years in each.

Bierich (1964) has described probable pituitary dwarfism in 2 sibs. The oldest measured $119 \mathrm{~cm}$. at 22 years. Menarche occurred at $15 \frac{3}{4}$ years, with regular menses thereafter, though the cycles were anovulatory. Breast development was normal, pubic hair scanty, axillary hair absent. Her dwarfed brother was only 10 years old at the time of the report. Growth hormone determinations had not been performed.

The 8 dwarfs described by Hanhart (1925) from Samnauntal, Switzerland, may also well have been examples of hereditary pituitary dwarfism with spontaneous puberty, though this cannot be proved. These patients showed spontaneous sexual maturation, though late and incomplete.

It may be convenient to summarize the varieties of hereditary (or probably hereditary) pituitary dwarfism which have up to now been delineated. (1) Isolated growth hormone deficiency with low serum GH (Rimoin et al., 1966; this report). (2) Pituitary dwarfism with high serum GH in radioimmunoassay, presumably biologically inactive (Laron et al., 1966). (3) Hypogonadotropic pituitary dwarfism (Hanhart, 1925; Trygstad and Seip, 1964; and others). (4) Aplasia of the pituitary gland (Steiner and Boggs, 1965).

Familial, hereditary hypogonadotropic hypogonadism without dwarfism or other signs of pituitary failure except gonadotropin deficiency have been described by Le Marquand (1954), Biben and Gordan (1955), and Lynch, Ozer, McNutt, Johnson, and Jampolsky (1960). Diabetes insipidus may also be genetically determined in some families. Isolated deficiences of thyrotropin (Shuman, 1953) and of ACTH (Steinberg, Shecter, and Segal, 1954; Odell, Green, and Williams, 1960; Cleveland, Green, and Migeon, 1960) have been reported, and some of these cases may be hereditary.

\section{Summary}

A family is reported in which 3 of 9 sibs, 2 males and 1 female, are pituitary dwarfs. The parents are first cousins. The patients have an isolated somatotropin deficiency, inherited as an autosomal recessive trait. Puberty was delayed, but occurred spontaneously, starting at about 17 . There were no signs of thyrotropin or corticotropin deficiency.
Plasma growth hormone levels were low, and there was no increase following insulin-induced hypoglycaemia.

The youngest patient has been treated with human growth hormone for 2 years with good result.

Of the genetic marker systems segregating in the family, calculations of linkage to this disease were indicative of free recombination concerning the $\mathrm{ABO}$ and MNS systems, and gave a very slight suggestion of linkage in the $\mathrm{Rh}$, Inv, Gc, and $\mathrm{Lp}$ systems (see Appendix).

We wish to thank Dr. M. K. Fagerhol, Mrs. S. K. Gundersen, Miss M. Hornberg, Dr. E. Monn, and Dr. T. Reinskou, for performing blood-, serum-, and enzyme-typing, Dr. A. G. Steinberg, Cleveland, for Inv typing, and Dr. T. Gedde-Dahl for valuable assistance with the linkage calculations.

\section{REFERENCES}

Antonin, J. M. F. (1961). Hypothalamo-hypophysärer Zwergwuchs mit spontaner Pubertät. Helv. paediat. Acta, 16, 267.

Biben, R. L., and Gordan, G. S. (1955). Familial hypogonadotropic eunuchoidism. f. clin. Endocr., 15, 931.

Bierich, J. R. (1964). On genetically determined pituitary dwarfism. Acta endocr. (Kbh), 45, Suppl. 89, 27.

Brasel, J. A., Wright, J. C., Wilkins, L., and Blizzard, R. M. (1965). An evaluation of seventy-five patients with hypopituitarism beginning in childhood. Amer. F. Med., 38, 484.

Cleveland, W. W., Green, O. C., and Migeon, C. J. (1960). A case of proved adrenocorticotropin deficiency. $\mathcal{f}$. Pediat., 57, 376.

Finney, D. J. (1940). The detection of linkage. Ann. Eugen. (Lond.), 10, 171.

Gedde-Dahl, T., and Monn, E. (1967). Linkage relations of the phosphoglucomutase (PGM) gene locus in man. Probable linkage to phenylthiocarbamide (PTC) taster locus. Acta genet. (Basel), 17, 482.

Greulich, W. W., and Pyle, S. I. (1959). Radiographic Atlas of Skeletal Development of the Hand and Wrist, 2 nd ed. Stanford University Press, Stanford.

Hanhart, E. (1925). Uber heredodegenerativen Zwergwuchs mit Dystrophia adipose-genitalis an Hand von Untersuchungen bei drei Sippen von proportionierten Zwergen. Arch. Klaus-Stift. Vererb.-Forsch., 1, 181.

Hewer, T. F. (1944). Ateleiotic dwarfism with normal sexual function: a result of hypopituitarism. f. Endocr., 3, 397.

Laron, Z., Pertzelan, A., and Mannheimer, S. (1966). Genetic pituitary dwarfism with high serum concentration of growth hormone. A new inborn error of metabolism? Israel $\mathfrak{f}$. med. Sci., 2, 152.

Le Marquand, H. S. (1954). Congenital hypogonadotropic hypogonadism in five members of a family, three brothers and two sisters. Proc. roy. Soc. Med., 47, 442.

Lynch, H. T., Ozer, F., McNutt, C. W., Johnson, J. E., and Jampolsky, N. A. (1960). Secondary male hypogonadism and congenital ichtyosis: association of two rare genetic diseases. Amer. F. hum. Genet., 12, 440.

Mohr, J. (1966). Genetics of fourteen marker systems : associations and linkage relations. Acta genet. (Basel), 16, 1.

Nowakowski, H., and Lenz, W. (1961). Genetic aspects in male hypogonadism. Recent Progr. Hormone Res., 17, 53.

Odell, W. D., Green, G. H., and Williams, R. H. (1960). Hypoadrenotropism: the isolated deficiency of adrenotropic hormone. F. clin. Endocr., 20, 1017.

Rimoin, D. L., Merimee, T. J., and McKusick, V. A. (1966). Growth-hormone deficiency in man: an isolated, recessively inherited defect. Science, 152, 1635.

Schărer, K., and Prader, A. (1960). Wachstum und Knochenreifung beim hypophysären Zwergwuchs in Abhängigkeit von Thyreoidea- und Nebennierenfunktion. Schweiz. med. Wschr., 90, 1349. 
Shuman, C. R. (1953). Hypothyroidism due to thyrotropin deficiency without other manifestations of hypopituitarism. $\mathfrak{F}$. clin. Endocr., 13, 795.

Smith, C. A. B. (1959). Some comments on the statistical methods used in linkage investigations. Amer. F. hum. Genet., 11 (4), 289.

Steinberg, A., Shechter, F. R., and Segal, H. I. (1954). True pituitary Addison's disease-a pituitary unitropic deficiency. f. clin. Endocr., 14, 1519.

Steiner, M. M., and Boggs, J. D. (1965). Absence of pituitary gland, hypothyroidism, hypoadrenalism and hypogonadism in a 17-year-old dwarf. ibid., 25, 1591.

Trygstad, O. (1965). The insulin-glucose tolerance test in pituitary growth retardation. Arch. Dis. Childh., 40, 508.

—, and Seip, M. (1964). Hereditary pituitary dwarfism treated with human growth hormone. Acta paediat. (Uppsala), 53, 527.

\section{APPENDIX}

\section{Linkage Calculations and Biochemical Data}

The possibility was explored of extracting information about genetic linkage between this form of pituitary dwarfism and genetic markers.

Segregation was found in the ABO, MNS, Rh, Inv, Gc, and $L p$ systems. The results of the linkage calculations are given in Tables III and IV. The estimates of the probabilities of free recombinations as analysed by the Morton-Smith method for $\mathrm{ABO}$ and MNS systems are 0.978 and 0.973 , respectively. The probabilities of linkage have thus been reduced from the $a$ priori value of $4 \cdot 5 \%$ to $2 \cdot 1 \%$ and $2 \cdot 7 \%$, respectively.

Given linkage, a closer linkage than $19 \%$ for $\mathrm{ABO}$ and $12 \%$ for MNS can be excluded ( $p=0.05$ for lower values).

The $a$ priori probability of linkage has been raised to an a posteriori probability of $5.3 \%$ for relation to the Rh system, $8 \cdot 2 \%$ for the Inv system, $5 \cdot 3 \%$ for the Gc system, and to $7 \cdot 1 \%$ for the Lp system.

The Fisher-Finney values for the Inv relation (Table IV) are explained by the fact that this method takes into account the four Inv homozygotes only (IV., 5, 6, 7, and 8). None of these four was dwarfed. Given linkage to the Inv system, an absolute linkage can be excluded, since the linkage phases of the parents are opposite.

The evidence of nanism-Rh linkage is slightly enhanced by the distribution of the $\mathrm{c} \mathrm{d}$ e gene complex in the family. Given linkage to $\mathrm{Rh}$, a closer linkage than $6 \%$ can be excluded at the $5 \%$ level of significance.

The amount of information is small in all relations (see Table IV), and it must be concluded that the genetic marker systems in this family show no convincing indication of linkage.

TABLE I

Linkage Data

\begin{tabular}{|c|c|c|c|c|c|c|c|c|c|c|c|}
\hline $\begin{array}{c}\text { Pedigree } \\
\text { No. }\end{array}$ & III. 5 & III. 8 & IV. 4 & IV. 5 & IV. 6 & IV. 7 & IV. 8 & IV. 9 & IV. 10 & IV. 11 & IV. 12 \\
\hline $\begin{array}{c}\text { Sex } \\
\text { Disease }\end{array}$ & $\underline{M}$ & $\underline{\mathbf{F}}$ & $\begin{array}{l}M \\
+\end{array}$ & $\underline{\mathbf{F}}$ & $\underline{\mathbf{F}}$ & $\mathbf{F}$ & $\underline{\mathbf{F}}$ & $\begin{array}{l}\mathrm{F} \\
+\end{array}$ & $\underline{M}$ & $\stackrel{M}{\mathbf{T}}$ & $\underline{\mathbf{M}}$ \\
\hline 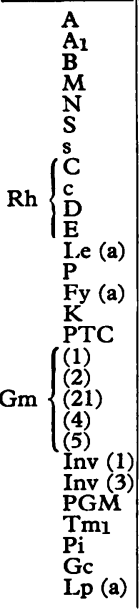 & $\begin{array}{c}- \\
+ \\
+ \\
\pm \\
+ \\
+ \\
+ \\
+ \\
+ \\
+ \\
+ \\
\pm \\
= \\
= \\
= \\
+ \\
+ \\
+ \\
+ \\
1-1 \\
+ \\
M M \\
1-1 \\
+\end{array}$ & $\begin{array}{c}+ \\
+ \\
+ \\
+ \\
+ \\
+ \\
+ \\
\pm \\
+ \\
+ \\
+ \\
+ \\
+ \\
\pm \\
\pm \\
= \\
\pm \\
\pm \\
+ \\
+ \\
+ \\
+ \\
1-1 \\
+ \\
M M \\
2-1 \\
+\end{array}$ & $\begin{array}{l}+ \\
+ \\
+ \\
+ \\
+ \\
+ \\
+ \\
+ \\
+ \\
+ \\
+ \\
+ \\
+ \\
- \\
- \\
= \\
+ \\
+ \\
+ \\
+ \\
1-1 \\
+ \\
M M \\
1-1 \\
+\end{array}$ & $\begin{array}{c}+ \\
+ \\
+ \\
+ \\
+ \\
+ \\
+ \\
+ \\
+ \\
+ \\
+ \\
+ \\
+ \\
- \\
- \\
- \\
+ \\
+ \\
+ \\
1-1 \\
+ \\
M M \\
2-1 \\
-\end{array}$ & $\begin{array}{c}- \\
+ \\
+ \\
+ \\
+ \\
\pm \\
\bar{y} \\
+ \\
+ \\
+ \\
+ \\
\pm \\
= \\
- \\
\overline{1} \\
+ \\
+ \\
+ \\
1-1 \\
+ \\
M M \\
1-1 \\
-\end{array}$ & $\begin{array}{c}+ \\
+ \\
+ \\
+ \\
+ \\
+ \\
+ \\
+ \\
+ \\
+ \\
+ \\
\pm \\
= \\
= \\
= \\
+ \\
+ \\
+ \\
1-1 \\
+ \\
M M \\
1-1 \\
+\end{array}$ & $\begin{array}{c}+ \\
+ \\
+ \\
+ \\
+ \\
+ \\
+ \\
+ \\
+ \\
+ \\
+ \\
+ \\
\pm \\
- \\
- \\
+ \\
+ \\
+ \\
1-1 \\
+ \\
M M \\
2-1 \\
+\end{array}$ & $\begin{array}{c}- \\
+ \\
+ \\
+ \\
+ \\
\pm \\
\pm \\
\pm \\
+ \\
+ \\
+ \\
- \\
- \\
- \\
+ \\
+ \\
+ \\
+ \\
1-1 \\
+ \\
M M \\
1-1 \\
+\end{array}$ & $\begin{array}{c}+ \\
+ \\
+ \\
+ \\
+ \\
+ \\
+ \\
+ \\
+ \\
+ \\
+ \\
+ \\
\pm \\
\pm \\
= \\
- \\
= \\
+ \\
+ \\
+ \\
+ \\
1-1 \\
+ \\
M M \\
1-1 \\
\end{array}$ & $\begin{array}{c}+ \\
\pm \\
+ \\
\pm \\
\pm \\
\pm \\
\pm \\
\pm \\
\pm \\
+ \\
+ \\
\pm \\
\pm \\
= \\
\pm \\
+ \\
+ \\
+ \\
+ \\
1-1 \\
+ \\
M M \\
1-1 \\
+\end{array}$ & $\begin{array}{c}+ \\
+ \\
+ \\
\pm \\
+ \\
+ \\
+ \\
+ \\
\pm \\
+ \\
+ \\
+ \\
+ \\
- \\
= \\
- \\
+ \\
+ \\
+ \\
+ \\
1-1 \\
+ \\
M M \\
1-1 \\
+\end{array}$ \\
\hline
\end{tabular}


TABLE II

Biochemical and Hormone Findings

\begin{tabular}{|c|c|c|c|c|c|c|c|c|}
\hline & & & & \multirow{2}{*}{$\begin{array}{l}\text { IV. } 4 \\
36 \text { yr. }\end{array}$} & \multicolumn{2}{|c|}{ IV. 9} & \multicolumn{2}{|c|}{ IV. 11} \\
\hline & & & & & $19 \mathrm{yr}$ & $21 \mathrm{yr}$ & $14 \mathrm{yr}$ & $16 \mathrm{yr}$. \\
\hline $\begin{array}{l}\text { Serum } \\
\text { Calcium (mEq/1.) } \\
\text { Phosphorus (mg./100 ml.) } \\
\text { Phosphatase (Bodansky units } \\
\text { Magnesium (mg./100 ml.) } \\
\text { Cholesterol (mg./100 ml.) } \\
\text { PBI ( } \mu \mathrm{g} . / 100 \mathrm{ml} .) \quad \ldots\end{array}$ & $\begin{array}{l}\cdots \\
\cdots \\
\cdots \\
\cdots\end{array}$ & $\begin{array}{l}\cdots \\
\cdots \\
\cdots \\
\cdots\end{array}$ & $\begin{array}{l}\ldots \\
\ldots \\
\ldots \\
\ldots \\
.\end{array}$ & $\begin{array}{l}4 \cdot 0 \\
2 \cdot 5 \\
3 \cdot 0 \\
1 \cdot 7 \\
340 \\
5 \cdot 5\end{array}$ & $\begin{array}{l}5 \cdot 5 \\
3 \cdot 3 \\
6 \cdot 7 \\
\\
360 \\
6 \cdot 8\end{array}$ & $\begin{array}{l}4 \cdot 4 \\
2 \cdot 8 \\
3 \cdot 5 \\
1 \cdot 3 \\
355 \\
6 \cdot 8\end{array}$ & $\begin{array}{r}5 \cdot 2 \\
3 \cdot 3 \\
12 \cdot 6 \\
\\
309 \\
7 \cdot 5\end{array}$ & $\begin{array}{r}4.7 \\
3.4 \\
16.5 \\
1.5 \\
334 \\
6.4\end{array}$ \\
\hline 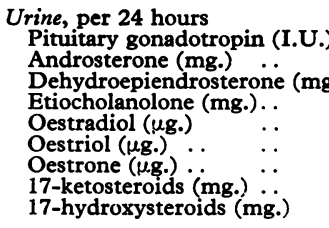 & $\begin{array}{l}\ddot{g} \\
\cdots \\
\ldots \\
\ldots \\
\cdots \\
\cdots\end{array}$ & $\begin{array}{l}\cdots \\
\cdots \\
\cdots \\
\cdots \\
\cdots \\
\cdots \\
\cdots\end{array}$ & \begin{tabular}{l|}
$\cdots$ \\
$\cdots$ \\
$\cdots$ \\
$\cdots$ \\
$\cdots$ \\
$\cdots$ \\
$\cdots$
\end{tabular} & $\begin{array}{l}162 \\
1 \cdot 8 \\
1 \cdot 2 \\
1 \cdot 2 \\
3 \cdot 9 \\
7 \cdot 7 \\
3 \cdot 2 \\
6 \cdot 1 \\
5 \cdot 2\end{array}$ & $\begin{array}{l}<5 \\
\\
1 \cdot 2 \\
2 \cdot 1 \\
1 \cdot 8 \\
0 \cdot 1 \\
1 \cdot 4\end{array}$ & $\begin{array}{l}39 \\
0 \cdot 8 \\
1 \cdot 4 \\
0 \cdot 9 \\
2 \cdot 3 \\
1 \cdot 6 \\
1 \cdot 3 \\
4 \cdot 0 \\
1 \cdot 9\end{array}$ & $\begin{array}{l}0 \cdot 1 \\
0 \cdot 9\end{array}$ & $\begin{array}{l}27 \\
0 \cdot 6 \\
0 \cdot 2 \\
0 \cdot 3 \\
1 \cdot 0 \\
0 \cdot 8 \\
1 \cdot 5 \\
1 \cdot 4 \\
2 \cdot 8\end{array}$ \\
\hline $\begin{aligned} \text { Insulin tolerance test } & \\
\text { Blood glucose : } 0 & \ldots \\
20 \mathrm{~min} . & \ldots \\
30 \mathrm{~min} . & \ldots\end{aligned}$ & $\begin{array}{l}\cdots \\
\cdots \\
\cdots\end{array}$ & $\begin{array}{l}\dot{*} \\
\dot{*}\end{array}$ & $\begin{array}{l}\ddot{*} \\
\cdots \\
\cdots\end{array}$ & $\begin{array}{l}99 \\
74 \\
60\end{array}$ & & $\begin{array}{l}74 \\
34 \\
36\end{array}$ & $\begin{array}{l}80 \\
32 \\
38\end{array}$ & $\begin{array}{l}82 \\
24 \\
43\end{array}$ \\
\hline $\begin{array}{l}\text { Plasma growth hormone, mug./n } \\
\text { Before insulin . } \\
60 \text { minutes after insulin }\end{array}$ & $\begin{array}{l}m \\
\cdots \\
\cdots\end{array}$ & $\ddot{*}$ & $\ddot{.}$ & $\begin{array}{l}1 \cdot 0 \\
1 \cdot 0\end{array}$ & & $\begin{array}{l}1 \cdot 3 \\
1 \cdot 8\end{array}$ & & $\begin{array}{l}1 \cdot 0 \\
1 \cdot 0\end{array}$ \\
\hline
\end{tabular}

TABLE III

Linkage Relations of Hereditary Pituitary Dwarfism (Morton-Smith Method): Probabilities of Free Recombination and Most Likely Recombination Frequencies in Case of Linkage. A priori Probability of Free Recombination: 0.9545

\begin{tabular}{c|c|c|c|c|c|c}
\hline System & ABO & MNS & Rh & Inv & Gc & Lp \\
\hline $\begin{array}{l}\text { Probability of free recombination finkage } \\
\text { Most likely recombination in case of linkage }\end{array}$ & 0.978 & 0.973 & $\begin{array}{l}0.947 \\
0.21\end{array}$ & 0.917 & 0.947 & 0.929 \\
\hline
\end{tabular}

TABLE IV

Linkage Relations of Hereditary Pituitary Dwarfism (Fisher-Finney Method)

\begin{tabular}{|c|c|c|c|c|c|c|c|c|c|c|}
\hline \multicolumn{5}{|c|}{ System } & ABO & MNS & Rh & Inv & Gc & Lp \\
\hline $\begin{array}{l}\text { Information } \\
\text { Linkage score } \\
\text { Test value } \\
\text { Recombination }\end{array}$ & $\begin{array}{l}\cdots \\
\cdots \\
\dot{\text { freque }}\end{array}$ & $\begin{array}{l}\ldots \\
\cdots \\
\ddot{n c y} \text { if linked }\end{array}$ & $\begin{array}{l}\cdots \\
\cdots \\
\cdots\end{array}$ & $\begin{array}{l}\cdots \\
\cdots \\
\cdots \\
\cdots\end{array}$ & $\begin{array}{r}6 \cdot 941 \\
-2 \cdot 999 \\
-1 \cdot 138\end{array}$ & $\begin{array}{r}4 \cdot 288 \\
-1 \cdot 333 \\
-0.643\end{array}$ & $\begin{array}{l}8 \cdot 577 \\
3 \cdot 5.55 \\
1 \cdot 214 \\
0 \cdot 178\end{array}$ & $\begin{array}{l}3 \cdot 763 \\
0 \\
0 \\
0 \cdot 500\end{array}$ & $\begin{array}{l}4 \cdot 288 \\
0 \cdot 888 \\
0 \cdot 429 \\
0 \cdot 272\end{array}$ & $\begin{array}{l}2 \cdot 048 \\
2 \cdot 068 \\
1 \cdot 444 \\
0\end{array}$ \\
\hline
\end{tabular}

